\title{
Disease Control Priorities in Developing Countries
}

SECOND EDITION 



\section{Disease Control Priorities in Developing Countries}

SECOND EDITION

\section{Editors}

Dean T. Jamison

Joel G. Breman

Anthony R. Measham

George Alleyne

Mariam Claeson

David B. Evans

Prabhat Jha

Anne Mills

Philip Musgrove 
(C)2006 The International Bank for Reconstruction and Development / The World Bank

1818 H Street NW

Washington DC 20433

Telephone: 202-473-1000

Internet: www.worldbank.org

E-mail: feedback@worldbank.org

All rights reserved

$\begin{array}{llllllll}1 & 2 & 3 & 4 & 09 & 08 & 07 & 06\end{array}$

A copublication of The World Bank and Oxford University Press.

Oxford University Press

165 Madison Avenue

New York NY 10016

This volume was funded in part by a grant from the Bill \& Melinda Gates Foundation and is a product of the staff of the International Bank for Reconstruction and Development / the World Bank, the World Health Organization, and the Fogarty International Center of the National Institutes of Health. The findings, interpretations, and conclusions expressed in this volume do not necessarily reflect the views of the executive directors of the World Bank or the governments they represent, the World Health Organization, or the Fogarty International Center of the National Institutes of Health.

The World Bank, the World Health Organization, and the Fogarty International Center of the National Institutes of Health do not guarantee the accuracy of the data included in this work. The boundaries, colors, denominations, and other information shown on any map in this work do not imply any judgement on the part of the World Bank, the World Health Organization, or the Fogarty International Center of the National Institutes of Health concerning the legal status of any territory or the endorsement or acceptance of such boundaries.

Rights and Permissions

The material in this publication is copyrighted. Copying and/or transmitting portions or all of this work without permission may be a violation of applicable law. The International Bank for Reconstruction and Development / The World Bank encourages dissemination of its work and will normally grant permission to reproduce portions of the work promptly.

For permission to photocopy or reprint any part of this work, please send a request with complete information to the Copyright Clearance Center Inc., 222 Rosewood Drive, Danvers, MA 01923, USA; telephone: 978-750-8400; fax: 978-750-4470; Internet: www.copyright.com. All other queries on rights and licenses, including subsidiary rights, should be addressed to the Office of the Publisher, The World Bank, $1818 \mathrm{H}$ Street NW, Washington, DC 20433, USA; fax: 202-522-2422; e-mail: pubrights@worldbank.org.

ISBN-10: 0-8213-0821361791

ISBN-13: 978-0-821-36179-5

eISBN: $\quad 0-8213-6180-5$

Library of Congress Cataloguing-in-Publication Data has been applied for. 


\section{Dedication}

This book is dedicated to Bill and Melinda Gates, whose vision, leadership, and financing over the past decade have catalyzed global support for transforming the lives of the world's poor through inexpensive but powerful health interventions. 



\section{Contents}

Foreword by Jaime Sepúlveda $\quad$ xiii

Preface xvii

Editors xix

Advisory Committee to the Editors xxiii

$\begin{array}{lll}\text { Contributors } & \text { Xxv }\end{array}$

Disease Control Priorities Project Partners $\quad$ xxxv

Acknowledgments $\quad$ xxxvii

$\begin{array}{ll}\text { Abbreviations and Acronyms } & \text { xxxix }\end{array}$

Part One Summary and Cross-Cutting Themes 1

Summary

Chapter 1 Investing in Health $\quad 3$

Dean T. Jamison

Chapter 2 Intervention Cost-Effectiveness: Overview of Main Messages 35

Ramanan Laxminarayan, Jeffrey Chow, and Sonbol A. Shahid-Salles

Chapter 3 Strengthening Health Systems

87

Anne Mills, Fawzia Rasheed, and Stephen Tollman

\section{Cross-Cutting Themes}

Chapter 4 Priorities for Global Research and Development of Interventions

Barry R. Bloom, Catherine M. Michaud, John R. La Montagne, and Lone Simonsen

Chapter 5 Science and Technology for Disease Control: Past, Present, and Future

David Weatherall, Brian Greenwood, Heng Leng Chee, and Prawase Wasi

Chapter 6 Product Development Priorities

Adel Mahmoud, Patricia M. Danzon, John H. Barton, and Roy D. Mugerwa

Chapter 7 Economic Approaches to Valuing Global Health Research

David Meltzer

Chapter 8 Improving the Health of Populations: Lessons of Experience 
Chapter 9 Millennium Development Goals for Health: What Will It Take to Accelerate Progress?

Adam Wagstaff, Mariam Claeson, Robert M. Hecht, Pablo Gottret, and Qiu Fang

Chapter 10 Gender Differentials in Health

Mayra Buvinić, André Médici, Elisa Fernández, and Ana Cristina Torres

Chapter 11 Fiscal Policies for Health Promotion and Disease Prevention

Rachel Nugent and Felicia Knaul

Chapter 12 Financing Health Systems in the 21st Century

George Schieber, Cristian Baeza, Daniel Kress, and Margaret Maier

Chapter 13 Recent Trends and Innovations in Development Assistance for Health

Robert M. Hecht and Raj Shah

Chapter 14 Ethical Issues in Resource Allocation, Research, and New Product Development

Dan W. Brock and Daniel Wikler

Chapter 15 Cost-Effectiveness Analysis for Priority Setting

Philip Musgrove and Julia Fox-Rushby

Part Two Selecting Interventions

Infectious Disease, Reproductive Health, and Undernutrition

Chapter 16 Tuberculosis

Christopher Dye and Katherine Floyd

Chapter 17 Sexually Transmitted Infections

Sevgi 0. Aral and Mead Over, with Lisa Manhart and King K. Holmes

Chapter 18 HIV/AIDS Prevention and Treatment

Stefano Bertozzi, Nancy S. Padian, Jeny Wegbreit, Lisa M. DeMaria, Becca Feldman, Helene Gayle, Julian Gold, Robert Grant, and Michael T. Isbell

Chapter 19 Diarrheal Diseases

Gerald T. Keusch, Olivier Fontaine, Alok Bhargava, Cynthia Boschi-Pinto, Zulfiqar A. Bhutta, Eduardo Gotuzzo, Juan A. Rivera, Jeffrey Chow, Sonbol A. Shahid-Salles, and Ramanan Laxminarayan

Chapter 20 Vaccine-Preventable Diseases

Logan Brenzel, Lara J. Wolfson, Julia Fox-Rushby, Mark Miller, and Neal A. Halsey

Chapter 21 Conquering Malaria

Joel G. Breman, Anne Mills, Robert W. Snow, Jo-Ann Mulligan, Christian Lengeler, Kamini Mendis, Brian Sharp, Chantal Morel, Paola Marchesini, Nicholas J. White, Richard W. Steketee, and Ogobara K. Doumbo

Chapter 22 Tropical Diseases Targeted for Elimination: Chagas Disease, Lymphatic Filariasis, Onchocerciasis, and Leprosy

Jan H. F. Remme, Piet Feenstra, P. R. Lever, André Médici, Carlos Morel, Mounkaila Noma, K. D. Ramaiah, Frank Richards, A. Seketeli, Gabriel Schmunis, W. H. van Brakel, and Anna Vassall

Chapter 23 Tropical Diseases Lacking Adequate Control Measures: Dengue, Leishmaniasis, and African Trypanosomiasis

Pierre Cattand, Phillippe Desjeux, M. G. Guzmán, Jean Jannin, A. Kroeger, André Médici, Philip Musgrove, Mike B. Nathan, Alexandra Shaw, and C. J. Schofield 
Chapter 24 Helminth Infections: Soil-Transmitted Helminth Infections and Schistosomiasis

Peter J. Hotez, Donald A. P. Bundy, Kathleen Beegle, Simon Brooker, Lesley Drake, Nilanthi de Silva, Antonio Montresor, Dirk Engels, Matthew Jukes, Lester Chitsulo, Jeffrey Chow, Ramanan Laxminarayan, Catherine M. Michaud, Jeff Bethony, Rodrigo Correa-Oliveira, Xiao Shu-Hua, Alan Fenwick, and Lorenzo Savioli

Chapter 25 Acute Respiratory Infections in Children

Eric A. F. Simoes, Thomas Cherian, Jeffrey Chow, Sonbol A. Shahid-Salles,

Ramanan Laxminarayan, and T. Jacob John

Chapter 26 Maternal and Perinatal Conditions

Wendy J. Graham, John Cairns, Sohinee Bhattacharya, Colin H. W. Bullough, Zahidul Quayyum, and Khama Rogo

Chapter 27 Newborn Survival

Joy E. Lawn, Jelka Zupan, Geneviève Begkoyian, and Rudolf Knippenberg

Chapter 28 Stunting, Wasting, and Micronutrient Deficiency Disorders Laura E. Caulfield, Stephanie A. Richard, Juan A. Rivera, Philip Musgrove, and Robert E. Black

Chapter 29 Health Service Interventions for Cancer Control in Developing Countries Martin L. Brown, Sue J. Goldie, Gerrit Draisma, Joe Harford, and Joseph Lipscomb

\section{Noncommunicable Disease and Injury}

Chapter 30 Diabetes: The Pandemic and Potential Solutions

K. M. Venkat Narayan, Ping Zhang, Alka M. Kanaya, Desmond E. Williams, Michael M. Engelgau, Giuseppina Imperatore, and Ambady Ramachandran

Chapter 31 Mental Disorders

Steven Hyman, Dan Chisholm, Ronald Kessler, Vikram Patel, and Harvey Whiteford

Chapter 32 Neurological Disorders

Vijay Chandra, Rajesh Pandav, Ramanan Laxminarayan, Caroline Tanner, Bala Manyam, Sadanand Rajkumar, Donald Silberberg, Carol Brayne, Jeffrey Chow, Susan Herman, Fleur Hourihan, Scott Kasner, Luis Morillo, Adesola Ogunniyi, William Theodore, and Zhen-Xin Zhang

Chapter 33 Cardiovascular Disease

Thomas A. Gaziano, K. Srinath Reddy, Fred Paccaud, Susan Horton, and Vivek Chaturvedi

Chapter 34 Inherited Disorders of Hemoglobin

David Weatherall, Olu Akinyanju, Suthat Fucharoen, Nancy Olivieri, and Philip Musgrove

Chapter 35 Respiratory Diseases of Adults

Frank E. Speizer, Susan Horton, Jane Batt, and Arthur S. Slutsky

Chapter 36 Diseases of the Kidney and the Urinary System

John Dirks, Giuseppe Remuzzi, Susan Horton, Arrigo Schieppati, and S. Adibul Hasan Rizvi

Chapter 37 Skin Diseases

Roderick Hay, Sandra E. Bendeck, Suephy Chen, Roberto Estrada, Anne Haddix, Tonya McLeod, and Antoine Mahé

Chapter 38 Oral and Craniofacial Diseases and Disorders

Douglas Bratthall, Poul Erik Petersen, Jayanthi Ramanathan Stjernswärd, and L. Jackson Brown

Chapter 39 Unintentional Injuries

Robyn Norton, Adnan A. Hyder, David Bishai, and Margie Peden 
Mark L. Rosenberg, Alexander Butchart, James Mercy, Vasant Narasimhan, Hugh Waters, and Maureen S. Marshall

Risk Factors

Chapter 41 Water Supply, Sanitation, and Hygiene Promotion

Sandy Cairncross and Vivian Valdmanis

Chapter 42 Indoor Air Pollution

Nigel Bruce, Eva Rehfuess, Sumi Mehta, Guy Hutton, and Kirk Smith

Chapter 43 Air and Water Pollution: Burden and Strategies for Control

Tord Kjellström, Madhumita Lodh, Tony McMichael, Geetha Ranmuthugala, Rupendra Shrestha, and Sally Kingsland

Chapter 44 Prevention of Chronic Disease by Means of Diet and Lifestyle Changes

Walter C. Willett, Jeffrey P. Koplan, Rachel Nugent, Courtenay Dusenbury, Pekka Puska, and Thomas A. Gaziano

Chapter 45 The Growing Burden of Risk from High Blood Pressure, Cholesterol, and Bodyweight

Anthony Rodgers, Carlene M. M. Lawes, Thomas A. Gaziano, and Theo Vos

Chapter 46 Tobacco Addiction

Prabhat Jha, Frank J. Chaloupka, James Moore, Vendhan Gajalakshmi, Prakash C. Gupta, Richard Peck, Samira Asma, and Witold Zatonski

Chapter 47 Alcohol

Jürgen Rehm, Dan Chisholm, Robin Room, and Alan D. Lopez

Chapter 48 Illicit Opiate Abuse

Wayne Hall, Chris Doran, Louisa Degenhardt, and Donald Shepard

\section{Consequences of Disease and Injury}

Chapter 49 Learning and Developmental Disabilities

Maureen S. Durkin, Helen Schneider, Vikram S. Pathania, Karin B. Nelson, Geoffrey C. Solarsh, Nicole Bellows, Richard M. Scheffler, and Karen J. Hofman

Chapter 50 Loss of Vision and Hearing

Joseph Cook, Kevin D. Frick, Rob Baltussen, Serge Resnikoff, Andrew Smith, Jeffrey Mecaskey, and Peter Kilima

Chapter 51 Cost-Effectiveness of Interventions for Musculoskeletal Conditions

Luke B. Connelly, Anthony Woolf, and Peter Brooks

Chapter 52 Pain Control for People with Cancer and AIDS

Kathleen M. Foley, Judith L. Wagner, David E. Joranson, and Hellen Gelband

\section{Part Three Strengthening Health Systems}

Strengthening Public Health Services

\section{Chapter 53 Public Health Surveillance: A Tool for Targeting and} Monitoring Interventions

Peter Nsubuga, Mark E. White, Stephen B. Thacker, Mark A. Anderson, Stephen B. Blount, Claire V. Broome, Tom M. Chiller, Victoria Espitia, Rubina Imtiaz, Dan Sosin, Donna F. Stroup, Robert V. Tauxe, Maya Vijayaraghavan, and Murray Trostle 
Sally K. Stansfield, Julia Walsh, Ndola Prata, and Timothy Evans

Ramanan Laxminarayan, Zulfiqar A. Bhutta, Adriano Duse, Philip Jenkins, Thomas O'Brien, Iruka N. Okeke, Ariel Pablo-Mendez, and Keith P. Klugman

Chapter 56 Community Health and Nutrition Programs

John B. Mason, David Sanders, Philip Musgrove, Soekirman, and Rae Galloway

Chapter 57 Contraception

Ruth Levine, Ana Langer, Nancy Birdsall, Gaverick Matheny, Merrick Wright, and Angela Bayer

Chapter 58 School-Based Health and Nutrition Programs

1091

Donald A. P. Bundy, Sheldon Shaeffer, Matthew Jukes, Kathleen Beegle, Amaya Gillespie, Lesley Drake, Seung-hee Frances Lee, Anna-Maria Hoffman, Jack Jones, Arlene Mitchell, Delia Barcelona, Balla Camara, Chuck Golmar, Lorenzo Savioli, Malick Sembene,

Tsutomu Takeuchi, and Cream Wright

Chapter 59 Adolescent Health Programs

Elizabeth Lule, James E. Rosen, Susheela Singh, James C. Knowles, and Jere R. Behrman

Chapter 60 Occupational Health

Linda Rosenstock, Mark Cullen, and Marilyn Fingerhut

Chapter 61 Natural Disaster Mitigation and Relief

Claude de Ville de Goyet, Ricardo Zapata Marti, and Claudio Osorio

Chapter 62 Control and Eradication

Mark Miller, Scott Barrett, and D. A. Henderson

\section{Strengthening Personal Health Services}

Chapter 63 Integrated Management of the Sick Child

Cesar G. Victora, Taghreed Adam, Jennifer Bryce, and David B. Evans

Chapter 64 General Primary Care

Stephen Tollman, Jane Doherty, and Jo-Ann Mulligan

Chapter 65 The District Hospital

Mike English, Claudio F. Lanata, Isaac Ngugi, and Peter C. Smith

Chapter 66 Referral Hospitals

Martin Hensher, Max Price, and Sarah Adomakoh

Chapter 67 Surgery

Haile T. Debas, Richard Gosselin, Colin McCord, and Amardeep Thind

Chapter 68 Emergency Medical Services

Olive C. Kobusingye, Adnan A. Hyder, David Bishai, Manjul Joshipura, Eduardo Romero Hicks, and Charles Mock

Chapter 69 Complementary and Alternative Medicine

Haile T. Debas, Ramanan Laxminarayan, and Stephen E. Straus

\section{Capacity Strengthening and Management Reform}

Chapter 70 Improving the Quality of Care in Developing Countries 
Chapter 72 Ensuring Supplies of Appropriate Drugs and Vaccines

1323

Susan Foster, Richard Laing, Bjørn Melgaard, and Michel Zaffran

Chapter 73 Strategic Management of Clinical Services

1339

Alexander S. Preker, Martin McKee, Andrew Mitchell, and Suwit Wilbulpolprasert

Glossary

1353

Index

1357

Credits

1401

xii | Contents 


\section{Foreword}

The 1993 publication of the now classic book, Disease Control Priorities in Developing Countries, by Oxford University Press and of its companion document, the World Development Report 1993: Investing in Health, published by the World Bank that same year, constitute a landmark in the public health literature. For the first time, decision makers and public health practitioners had a comprehensive review of the cost-effectiveness of available interventions to address the most common health problems in the developing world. They were also provided with the useful metric known as disability-adjusted life years to calculate the burden of disease and the cost-effectiveness of interventions more accurately than in the past.

As was the case with the first edition, this second edition of Disease Control Priorities in Developing Countries will serve an array of audiences. One primary audience consists of people working in the health sector, ranging from those who are responsible for making evidence-based decisions to those who practice medicine and public health under often suboptimal field conditions. A second audience consists of people working in finance and planning ministries, who will benefit from the solid recommendations for improving the health of populations through sound resource reallocation and cost-effective practices.

\section{PURPOSE}

The purpose of this book is to provide information about what works-specifically, the cost-effectiveness of health interventions in a variety of settings. Such information should influence the redesign of programs and the reallocation of resources, thereby helping to achieve the ultimate goal of reducing morbidity and mortality.

\section{FUNDAMENTAL POLICY CONSIDERATIONS}

Although economic and budgetary constraints are clearly important considerations, money is not the only limitation. Additional factors fundamental to improving outcomes are the particular circumstances in each country, as well as the individual institutional capacities to deliver goods and services and to implement policies and processes.

Context-specific strategies and responses are essential, because application of the Disease Control Priorities Project's findings will vary according to each country's circumstances: one size does not fit all. Understanding that most health interventions require a minimum level of institutional capacity to deliver goods and services is equally important, and such capacity may have to be built up before money or physical inputs can yield any benefits. Accordingly, goals and priorities should be established and tailored to each country's context.

\section{TRANSITION IN HEALTH}

Every developing region is facing a transition in its epidemiological profile from an environment with high fertility rates and high mortality from preventable causes to one in which a combination of lower fertility rates and changing lifestyles has led to aging populations and epidemics of tobacco addiction, obesity, cardiovascular disease, cancers, diabetes, and other chronic ailments. The 20th century will be remembered for, among other things, witnessing the largest universal increase in life expectancy in history. While life expectancy is highest in the richest countries, the upward trend is apparent in almost every society. Moreover, in the past 50 years, variations in this health indicator across and within countries have decreased. This convergence of improved life expectancy and reduced variations, which has occurred even in the presence of widening income gaps in many regions, can be explained solely by the impact of knowledge expansion and direct public health interventions.

The increase in life expectancy worldwide will, however, soon reach a plateau, and a retraction has occurred in many countries. HIV/AIDS and civil unrest in Africa, vaccinepreventable diseases and alcoholism in Eastern Europe, and obesity in the United States have reduced-or will soon do so- - the years of life their populations can expect. 


\section{SCALING UP EFFECTIVE INTERVENTIONS}

The late Jim Grant, former executive director of the United Nations Children's Fund, was one of the first leaders with a vision for setting specific health goals and priorities within a time frame and on a global scale. He recognized the need to raise awareness of the dramatic disparities in children's health and to mobilize political will accordingly. His missionary zeal for universal child immunization and for organizing the first summit of world leaders for children's health and rights in 1990 permitted the scaling up of interventions of proven efficacy. The Millennium Development Goals are a natural consequence of that vision and an extremely useful instrument for maintaining both focus and social pressure. Achieving these ambitious goals will require not only the universal implementation of effective interventions that are currently available, but also the development of new interventions.

\section{NEED FOR ONGOING RESEARCH}

Today, most vaccines, medical devices, diagnostic tools, and drugs have been subjected to careful investigation in the laboratory, at the bedside, and in the field. However, not enough investment has gone into research to increase well-being and development globally. We need more epidemiological and health systems research to improve the efficiency of available interventions, technological research to reduce their costs, and biomedical research to develop new tools for dealing with as yet unsolved and emerging health problems.

\section{OPPORTUNITIES AND CHALLENGES OF GLOBALIZATION}

One of the greatest opportunities and challenges for international public health is globalization. We live in an era when the explosion of trade, travel, and communications is spreading new cultural influences and lifestyles faster than ever before, and the division between domestic and international health problems is becoming increasingly obsolete. At the same time, globalization also permits the spread of risks, pathogens, and other threats. The ever-increasing movement of people everywhere increases the potential for epidemics. Travelers, refugees, and displaced people are more vulnerable to infectious diseases, and their movement contributes to spreading pathogens into new areas. Overall, however, the positive consequences outweigh the negative ones, and cautious optimism about this irreversible trend is justified. Certainly, one of the most valuable contributions of globalization is the rapid accrual and spread of knowledge about useful tools for controlling disease and ways to implement those tools on a large scale.

In recent years, the huge advances in information technology have greatly boosted the globalization of knowledge.
Ideally, this should become a tide that lifts all boats to yield global benefits. The challenge is to harness the information technology revolution to foster the growth of economies. One step in the right direction is the open access movement, which promotes and permits free and immediate access to research results and other components of knowledge transfer.

\section{SPENDING MORE AND SPENDING BETTER}

It is indeed a paradox to observe that even though the money spent on health worldwide has reached 10 percent of overall global income, that amount is both insufficient and poorly allocated. The World Health Organization's Commission on Macroeconomics and Health and several other global initiatives make a persuasive plea for a larger investment in health. At the same time, this book is dedicated to making the case for better spending - that is, deriving more health benefits from every dollar spent. The aim should be to reduce inequalities in health investment between and within countries: a 100-fold difference between the rich and the poor in money spent on health services still persists in many places. Despite a lack of clarity about what constitutes the optimum balance of health spending, a larger share should go to prevention. This book looks at several prevention options and clinical interventions that are not being fully implemented.

\section{SELECTING INTERVENTIONS}

This book persuasively makes the case that both clinical and public health interventions depend on the capacity of a given country's health system to deliver, noting that some interventions are more demanding than others in terms of infrastructure and human resources. Therefore, both the costs and the likelihood of success of the more complex interventions are a function of the health capacity in place. In addition, decisions about which interventions should be given priority will depend on assessments of the local burden of disease, local health infrastructure, and other social factors as well as on cost-effectiveness analyses. The following chapters identify the health system capacity needed for scaling up a given intervention. Even middle-income countries with relatively better health infrastructure often pursue sophisticated approaches to medical care that result in fewer health gains per amount of money invested. Every country, regardless of level of development, could benefit from the recommendations presented here.

\section{DIAGONAL APPROACH}

The medical literature has long debated which approach to delivering health interventions is more effective: vertical programs or horizontal programs. Vertical programs refer to 
focused, proactive, disease-specific interventions on a massive scale, whereas horizontal programs refer to more integrated, demand-driven, resource-sharing health services. This is a false dilemma, because both need to coexist in what could be called a diagonal approach - that is, the proactive, supply-driven provision of a set of highly cost-effective interventions on a large scale that bridges health clinics and homes. This approach often starts vertically (polio vaccination, for instance) but moves toward an increasing number of interventions (for example, oral rehydration, other vaccines, residual spraying and bednets for malaria control, micronutrient supplementation, and supervised tuberculosis treatment), making full use of field health workers and existing infrastructure. This could well be the equivalent of a public health polypill.

\section{MULTIDISCIPLINARY ORIENTATION}

What makes this book unique, in addition to its comprehensive scope, is its truly multidisciplinary approach to disease control, which merges the best of the medical and economic sciences. Every recommendation has been carefully researched and documented. Evidence-based approaches must be the foundation for allocating scarce resources. The poor cannot afford anything but the most efficient methods for organizing and implementing health care. This book is a fundamental component for fostering equitable outcomes in health and development. It will inspire all those who seek the highly complex but attainable goal of universal good health for all members of the global community.

\section{FACILITATING PROGRESS}

We all share global responsibility: governments and international agencies, public and private sectors, and society and individuals all have specific tasks. We must all strive toward more equitable distribution of the benefits of new knowledge to reduce health and development gaps between rich and poor, between countries, and within countries. The second edition of Disease Control Priorities in Developing Countries is a new step in precisely the right direction. If we succeed in conveying the main lessons and messages of this book, public health in developing countries will progress farther and faster.

Jaime Sepúlveda, Director, National Institutes of Health of Mexico, Mexico City, Mexico

Chair, Advisory Committee to the Editors 



\section{Preface}

In the late 1980s, the World Bank initiated a review of priorities for the control of specific diseases and used this information as input for comparative cost-effectiveness estimates of interventions addressing most conditions important in developing countries. The purpose of the comparative cost-effectiveness work was to inform decision making within the health sectors of highly resource-constrained low- and middle-income countries. This process resulted in the 1993 publication of the first edition of Disease Control Priorities in Developing Countries (DCP1) (Jamison and others 1993). That volume's preface stated its purpose as follows:

Between 1950 and 1990, life expectancy in developing countries increased from forty to sixty-three years with a concomitant rise in the incidence of the noncommunicable diseases of adults and the elderly. Yet there remains a huge unfinished agenda for dealing with undernutrition and the communicable childhood diseases. These trends lead to increasingly diverse and complicated epidemiological profiles in developing countries. At the same time, new epidemic diseases like AIDS are emerging; and the health of the poor during economic crisis is a source of growing concern. These developments have intensified the need for better information on the effectiveness and cost of health interventions. To assist countries to define essential health service packages, this book provides information on disease control interventions for the commonest diseases and injuries in developing countries.

To this end, $D C P 1$ aimed to provide systematic guidance on the selection of interventions to achieve rapid health improvements in an environment of highly constrained public sector budgets through the use of cost-effectiveness analysis.

$D C P 1$ provided limited discussion of investments in health system development. Other major efforts undertaken at the World Bank at about the same time, including the World Development Report 1993: Investing in Health, used the findings of $D C P 1$ and dealt more explicitly with the financial and health systems aspects of implementation (Feachem and others 1992;
World Bank 1993). Closely related efforts in collaboration with the World Health Organization led to the first global and regional estimates of numbers of deaths by age, sex, and cause and of the burden (including the disability burden) from more than 100 specific diseases and conditions (Murray, Lopez, and Jamison 1994; World Bank 1993).

This second edition of Disease Control Priorities in Developing Countries (DCP2) seeks to update and improve guidance on the "what to do" questions in $D C P 1$ and to address the institutional, organizational, financial, and research capacities essential for health systems to deliver the right interventions. DCP2 is the principal product of the Disease Control Priorities Project, an alliance of organizations designed to review, generate, and disseminate information on how to improve population health in developing countries. In addition to $D C P 2$, the project produced numerous background papers, an extensive range of interactive consultations held around the world, and several additional major publications. The other major publications are as follows:

- Global Burden of Disease and Risk Factors (Lopez and others 2006), undertaken in collaboration with the World Health Organization

- Millions Saved: Proven Successes in Global Health (Levine and the What Works Working Group 2004), undertaken in collaboration with the Center for Global Development

- "The Intolerable Burden of Malaria: II. What's New, What's Needed" (Breman, Alilio, and Mills 2004), undertaken in collaboration with the Multilateral Initiative on Malaria

- Priorities in Health (Jamison and others 2006), a brief and nontechnical companion to this volume.

Each product of the Disease Control Priorities Project marries economic approaches with those of epidemiology, public health, and clinical medicine.

While general lessons emerge from the Disease Control Priorities Project, they result from careful consideration of individual cases. The diversity of health conditions necessitates specificity of analysis. Arrow clearly stated the need for 
technical analyses to underpin health economics: "Another lesson of medical economics is the importance of recognizing the specific character of the disease under consideration. The policy challenges that arise in treating malaria are simply very different from those attached to other major infectious scourges (Arrow, Panosian, and Gelband 2004, xi-xii)." Chapters in this volume address this need for specificity, yet use costeffectiveness analysis in a way that makes findings on the relative attractiveness of interventions comparable.

$D C P 2$ goes beyond $D C P 1$ in a number of important ways as follows:

- While virtually all chapters of $D C P 1$ were structured around clusters of conditions, DCP2 provides integrative chapters-for example, on school health systems, surgery, and integrated management of childhood illness-that draw together the implementation-related responses to a number of conditions. These and other chapters reflect $D C P 2$ 's inclusion of implementation and system issues.

- DCP2 includes explicit discussions of research and product development opportunities.

- Although DCP1 dealt with policy mechanisms to change behavior (or the environment), $D C P 2$ attempts to do so in a more systematic way. In particular, a number of chapters assess in depth the public sector instruments for influencing behavior change that were described briefly in $D C P 1$ : information, education, and communication; laws and regulations; taxes and subsidies; engineering design, such as speed bumps; and facility location and characteristics.

- Different interventions place different levels of demand on a country's health system capacity. DCP2 builds on earlier work (Gericke and others 2005) in attempting, in some chapters, to identify which interventions require relatively less system capacity for scaling up and which require more.

- Although DCP1 briefly discussed the nonhealth outcomes of interventions, $D C P 2$ does so in a more systematic way, including looking at the consequences of interventions (and intervention financing) for reducing financial risks at the household level. Other important nonhealth outcomes include, for example, the time-saving value of having piped water close to the home, the increased labor productivity of healthy workers, and the amenity value of clean air.

- An important element of DCP1 was its assumption that to inform broad policy, major changes from the status quo need to be considered, not just marginal ones. For costeffectiveness analysis, any major change needs to be informed by burden of disease assessments in a way not required for judging the attractiveness of marginal change, because the size of the burden affects total costs and the feasibility of extending the intervention to all who would benefit. This is particularly true when considering research and development priorities, but also applies to control priorities. In this regard, $D C P 2$ continues in the spirit of $D C P 1$ in assessing cost-effectiveness analyses of major changes, but it does so more systematically for each of the six regional groupings of low- and middle-income countries used throughout this volume (see map 1, inside the front cover).

What was becoming clear in 1990 is clearer today: focusing health system attention on delivering efficacious and often relatively inexpensive health interventions can lead to dramatic reductions in mortality and disability at modest cost. A valuable dimension of globalization has been the diffusion of knowledge about what these interventions are and how to deliver them. The pace of this diffusion into a country determines the pace of health improvement in that country much more than its level of income. Our purpose is to help speed this diffusion of life-saving knowledge.

The Editors

\section{REFERENCES}

Arrow, K. J., C. Panosian, and H. Gelband, eds. 2004. Saving Lives, Buying Time: Economics of Malaria Drugs in an Age of Resistance. Washington, DC: National Academies Press.

Breman, J. G., M. S. Alilio, and A. Mills, eds. 2004. “The Intolerable Burden of Malaria: II. What's New, What's Needed." American Journal of Hygiene and Tropical Medicine 71 (2 Suppl): 1-282.

Feachem, R. G. A., T. Kjellstrom, C. J. L. Murray, M. Over, and M. Phillips, eds. 1992. Health of Adults in the Developing World. New York: Oxford University Press.

Gericke, C. A., C. Kurowski, M. K. Ranson, and A. Mills. 2005. "Intervention Complexity: A Conceptual Framework to Inform Priority-Setting in Health." Bulletin of the World Health Organization 83 (4): 285-93.

Jamison, D. T., J. G. Breman, A. R. Measham, G. Alleyne, M. Claeson, D. B. Evans, P. Jha, A. Mills and P. Musgrove, eds. 2006. Priorities in Health. Washington, DC: World Bank.

Jamison, D. T., W. H. Mosley, A. R. Measham, and J. L. Bobadilla, eds. 1993. Disease Control Priorities in Developing Countries. New York: Oxford University Press.

Levine, R., and the What Works Working Group. 2004. Millions Saved: Proven Successes in Global Health. Washington, DC: Center for Global Development.

Lopez A. D., C. D. Mathers, M. Ezzati, D. T. Jamison, and C. J. L. Murray, eds. 2006. Global Burden of Disease and Risk Factors. New York: Oxford University Press.

Murray, C. J. L., A. D. Lopez, and D. T. Jamison. 1994. "The Global Burden of Disease in 1990: Summary Results, Sensitivity Analysis, and Future Directions." In Global Comparative Assessments in the Health Sector: Disease Burden, Expenditures, and Intervention Packages, ed. C. J. L. Murray, and A. D. Lopez, 97-138. Geneva: World Health Organization.

World Bank. 1993. World Development Report 1993: Investing in Health. New York: Oxford University Press. 


\section{Editors}

Dean T. Jamison is a professor of health economics in the School of Medicine at the University of California, San Francisco (UCSF), and an affiliate of UCSF Global Health Sciences. Dr. Jamison concurrently serves as an adjunct professor in both the Peking University Guanghua School of Management and in the University of Queensland School of Population Health.

Before joining UCSF, Dr. Jamison was on the faculty of the University of California, Los Angeles, and also spent many years at the World Bank, where he was a senior economist in the research department; division chief for education policy; and division chief for population, health, and nutrition. In 1992-93, he temporarily rejoined the World Bank to serve as director of the World Development Report Office and as lead author for the Bank's World Development Report 1993: Investing in Health.

His publications are in the areas of economic theory, public health, and education. Dr. Jamison studied at Stanford (B.A., philosophy; M.S., engineering sciences) and at Harvard (Ph.D., economics, under K. J. Arrow). In 1994, he was elected to membership in the Institute of Medicine of the U.S. National Academy of Sciences.

Joel G. Breman, M.D., D.T.P.H., is senior scientific adviser, Fogarty International Center of the National Institutes of Health, and comanaging editor of the Disease Control Priorities Project. He was educated at the University of California, Los Angeles; the Keck School of Medicine, the University of Southern California; and the London School of Hygiene and Tropical Medicine. Dr. Breman trained in medicine at the University of Southern California-Los Angeles County Medical Center; in infectious diseases at the Boston City Hospital, Harvard Medical School; and in epidemiology at the U.S. Centers for Disease Control and Prevention.

Dr. Breman worked in Guinea on smallpox eradication (1967-69); in Burkina Faso at the Organization for Coordination and Cooperation in the Control of the Major Endemic Diseases (1972-76); and at the World Health Organization, Geneva (1977-80), where he was responsible for orthopoxvirus research and the certification of smallpox eradication. In 1976, in the Democratic Republic of Congo (formerly Zaire), Dr. Breman investigated the first outbreak of Ebola hemorrhagic fever.

Following the confirmation of smallpox eradication in 1980, Dr. Breman returned to the U.S. Centers for Disease Control, where he began work on the epidemiology and control of malaria. Dr. Breman joined the Fogarty International Center in 1995 and has been director of the International Training and Research Program in Emerging Infectious Diseases and senior scientific adviser. He has been a member of many advisory groups, including serving as chair of the World Health Organization's Technical Advisory Group on Human Monkeypox and as a member of the World Health Organization's International Commission for the Certification of Dracunculiasis (guinea worm) Eradication. Dr. Breman has written more than 100 publications on infectious diseases and research capacity strengthening in developing countries. He was guest editor of two supplements to the American Journal of Tropical Medicine and Hygiene: "The Intolerable Burden of Malaria: A New Look at the Numbers" (2001) and "The Intolerable Burden of Malaria: What's New, What's Needed" (2004).

Anthony R. Measham is co-managing editor of the Disease Control Priorities Project at the Fogarty International Center of the National Institutes of Health; deputy director of the Communicating Health Priorities Project at the Population Reference Bureau, Washington, DC; and a member of the Working Group of the Global Alliance for Vaccines and Immunization on behalf of the World Bank.

Born in the United Kingdom, Dr. Measham practiced family medicine in Dartmouth, Nova Scotia, before devoting the remainder of his career to date to international health. He spent 15 years living in developing countries on behalf of the Population Council (Colombia), the Ford Foundation (Bangladesh), and the World Bank (India). Early in his international health career (1975-77), he was deputy director of the Center for Population and Family Health at Columbia University, New York. He then served for 17 years on the staff 
of the World Bank, as health adviser from 1984 until 1988 and as chief for policy and research of the Health, Nutrition, and Population Division from 1988 until 1993.

Dr. Measham has spent most of his career providing technical assistance, carrying out research and analysis, and helping to develop projects in more than 20 developing countries, primarily in the areas of maternal and child health, family planning, and nutrition. He was an editor of the first edition of Disease Control Priorities in Developing Countries and has authored approximately 60 monographs, book chapters, and journal articles.

Dr. Measham graduated in medicine from Dalhousie University, Halifax, Nova Scotia. He received a master of science and a doctorate in public health from the University of North Carolina in Chapel Hill and is a diplomat of the American Board of Preventive Medicine and Public Health. His honors include being elected to the Alpha Omega Alpha Honor Medical Society; being appointed as special professor of International Health, University of Nottingham Medical School, Nottingham, United Kingdom; and being named Dalhousie University Medical Alumnus of the Year in 2000-1.

George Alleyne, M.D., F.R.C.P., F.A.C.P. (Hon.), D.Sc. (Hon.), is director emeritus of the Pan American Health Organization, where he served as director from 1995 to 2003. Dr. Alleyne is a native of Barbados and graduated from the University of the West Indies in medicine in 1957. He completed his postgraduate training in internal medicine in the United Kingdom and did further postgraduate work in that country and in the United States. He entered academic medicine at the University of the West Indies in 1962, and his career included research in the Tropical Metabolism Research Unit for his doctorate in medicine. He was appointed professor of medicine at the University of the West Indies in 1972, and four years later he became chair of the Department of Medicine. He is an emeritus professor of the University of the West Indies. Dr. Alleyne joined the Pan American Health Organization in 1981, in 1983 he was appointed director of the Area of Health Programs, and in 1990 he was appointed assistant director.

Dr. Alleyne's scientific publications have dealt with his research in renal physiology and biochemistry and various aspects of clinical medicine. During his term as director of the Pan American Health Organization, he dealt with and published on issues such as equity in health, health and development, and international cooperation in health. He has also addressed several aspects of health in the Caribbean and the problems the area faces. He is a member of the Institute of Medicine and chancellor of the University of the West Indies.

Dr. Alleyne has received numerous awards in recognition of his work, including prestigious decorations and national honors from many countries of the Americas. In 1990, he was made Knight Bachelor by Her Majesty Queen Elizabeth II for his services to medicine. In 2001, he was awarded the Order of the Caribbean Community, the highest honor that can be conferred on a Caribbean national.

Mariam Claeson, M.D., M.P.H., is the program coordinator for AIDS in the South Asia Region of the World Bank since January 2005. She was the lead public health specialist in the Health, Nutrition, and Population, Human Development Network, of the World Bank (1998-2004), managing the Health, Nutrition, and Population Millennium Development Goals work program to support accelerated progress in countries.

Dr. Claeson coauthored the call for action by the Bellagio study group on child survival in 2003, Knowledge into Action for Child Survival, and the World Bank's 2005 report on The Millennium Development Goals for Health: Rising to the Challenges. She was a member of the What Works Working group hosted by the Center for Global Development that resulted in the report Millions Saved: Proven Successes in Global Health (2005). Dr. Claeson coauthored the health chapter of the Poverty Reduction Strategy source book, promoting a life-cycle approach to maternal and child health and nutrition. As a coordinator of the public health thematic group (1998-2002), she led the development of the strategy note Public Health and World Bank Operations and promoted multisectoral approaches to child health within the World Bank and in Bank-supported country operations, analytical work, and lending.

Prior to joining the World Bank, Dr. Claeson worked with the World Health Organization from 1987 until 1995, in later years as program manager for the Global Program for the Control of Diarrheal Diseases. She has several years of field experience working in developing countries; in clinical practice at the rural district level in Bangladesh, Bhutan, and Tanzania; in national program management of immunization and diarrheal disease control programs in Ethiopia; and in health sector development projects in middle- and low-income countries.

David B. Evans, Ph.D., is an economist by training. Between 1980 and 1990, he was an academic, first in economics departments and then in a medical school, during which time he undertook consultancies for the World Bank, the World Health Organization, and governments. From 1990 until 1998, he sponsored and conducted research into social and economic aspects of tropical diseases and their control in the United Nations Children's Fund, United Nations Development Programme, World Bank, and World Health Organization Special Programme on Research and Training in Tropical Diseases. He subsequently became director of the Global Programme on Evidence for Health Policy and then the Department of Health Systems Financing of the World Health Organization, where he is now responsible for a range of activities relating to the development of appropriate health 
financing strategies and policies. These activities include the World Health Organization's CHOICE project, which has assessed and reported the costs and effectiveness of more than 700 health interventions, the costs of scaling up interventions, the levels of health expenditures and accounts, and the extent of financial catastrophe and impoverishment caused by out-ofpocket payments for health and which has assessed the impact of different ways to raise funds for health, pool them, and use them to provide or purchase services and interventions. He has published widely in these areas.

Prabhat Jha is Canada research chair of health and development at the University of Toronto. He is also the founding director of the Centre for Global Health Research, St. Michael's Hospital; associate professor in the Department of Public Health Sciences, University of Toronto; research scholar at the McLaughlin Centre for Molecular Medicine; and professeur extraordinaire at the Université de Lausanne, Switzerland.

Dr. Jha is lead author of Curbing the Epidemic: Governments and the Economics of Tobacco Control and coeditor of Tobacco Control in Developing Countries. Both are among the most influential books on tobacco control. He is the principal investigator of a prospective study of 1 million deaths in India, researching mortality from smoking, alcohol use, fertility patterns, indoor air pollution, and other risk factors among 2.3 million homes and 15 million people. This work is currently the world's largest prospective study of health. He also conducts studies of HIV transmission in various countries, focusing on documenting the risk factors for the spread of HIV and interventions to prevent the spread of the HIV/AIDS epidemic. His studies have received more than $\$ 5$ million in peer-reviewed grants.

Dr. Jha has published widely on tobacco, HIV/AIDS, and health of the global poor. His awards include a Gold medal from the Poland Health Promotion Foundation (2000), the Top 40 Canadians under Age 40 Award (2004), and the Ontario Premier's Research Excellence Award (2004). Dr. Jha was a research scholar at the University of Toronto and McMaster University in Canada. He holds an M.D. from the University of Manitoba and a D. Phil. in epidemiology and public health from Oxford University, where he studied as a Rhodes Scholar at Magdalen College.

Anne Mills, Ph.D., is professor of health economics and policy at the London School of Hygiene and Tropical Medicine. She has more than 20 years of experience in research pertaining to health economics in developing countries and has published widely in the fields of health economics and health planning, including books on the role of government in health in developing countries, health planning in the United Kingdom, decentralization, health economics research in developing countries, and the public-private mix. Her most recent research interests have been in the organization and financing of health systems, including the evaluation of contractual relationships between the public and private sectors and the application of economic evaluation techniques to improve the efficiency of disease control programs.

Dr. Mills has had extensive involvement in supporting the health economics research activities of the World Health Organization's Tropical Disease Research Programme. She founded, and is head of, the Health Economics and Financing Programme, which has become one of the world's leading groups in developing and applying theories and techniques of health economics to increase knowledge on how best to improve the equity and efficiency of developing countries' health systems. She has acted as adviser to a number of multilateral and bilateral agencies - notably, the United Kingdom Department for International Development and the World Health Organization. She guided the creation of the Alliance for Health Policy and Systems Research and chairs its board. Most recently, she has been a member of the Commission for Macroeconomics and Health and cochair of its working group on improving the health outcomes of the poor.

Philip Musgrove is deputy editor-global health for Health Affairs, which is published by Project HOPE in Bethesda, Maryland. He worked for the World Bank (1990-2002), including two years on secondment to the World Health Organization (1999-2001), retiring as a principal economist. He was previously an adviser in health economics at the Pan American Health Organization (1982-90) and a research associate at the Brookings Institution and at Resources for the Future (1964-81).

Dr. Musgrove is an adjunct professor at the School of Advanced International Studies, Johns Hopkins University, and has taught at George Washington University, American University, and the University of Florida. He holds degrees from Haverford College (B.A., 1962, summa cum laude); Princeton University (M.P.A., 1964); and Massachusetts Institute of Technology (Ph.D., 1974).

Dr. Musgrove has worked on health reform projects in Argentina, Brazil, Chile, and Colombia and has dealt with a variety of issues in health economics, financing, equity, and nutrition. His publications include more than 50 articles in economics and health journals and chapters in 20 books. 



\title{
Advisory Committee to the Editors
}

\author{
J. R. Aluoch \\ Professor, Nairobi Women's Hospital, Nairobi, Kenya \\ Jacques Baudouy \\ Director, Health, Nutrition, and Population, World Bank, \\ Washington, DC, United States \\ Fred Binka \\ Executive Director, INDEPTH Network, Accra, Ghana \\ Mayra Buvinić \\ Director, Gender and Development, World Bank, \\ Washington, DC, United States \\ David Challoner, Co-Chair \\ Foreign Secretary, Institute of Medicine, \\ U.S. National Academies, Gainesville, Florida, \\ United States \\ Guy de Thé, Co-Chair \\ Research Director and Professor Emeritus, Institut Pasteur, \\ Paris, France \\ Timothy Evans \\ Assistant Director General, Evidence and Information for \\ Policy, World Health Organization, Geneva, Switzerland \\ Richard Horton \\ Editor, The Lancet, London, United Kingdom \\ Sharon Hrynkow \\ Acting Director, Fogarty International Center, National \\ Institutes of Health, Bethesda, Maryland, \\ United States

\section{Gerald Keusch} \\ Provost and Dean for Global Health, Boston University \\ School of Public Health, Boston, Massachusetts, \\ United States \\ Kiyoshi Kurokawa \\ President, Science Council of Japan, Kanawaga, Japan
}

\section{Peter Lachmann}

Past President, U.K. Academy of Medical Sciences, Cambridge, United Kingdom

\section{Mary Ann Lansang}

Executive Director, INCLEN Trust International Inc., Manila, Philippines

\section{Christopher Lovelace}

Director, Kyrgyz Republic Country Office and Central Asia Human Development, World Bank, Bishkek, Kyrgyz Republic

\section{Anthony Mbewu}

Executive Director, Medical Research Council of South Africa, Tygerberg, South Africa

\section{Rajiv Misra}

Former Secretary of Health, Government of India, Haryana, India

\section{Perla Santos Ocampo}

President, National Academy of Science and Technology,

San Juan, Philippines

\section{G. B. A. Okelo}

Secretary General and Executive Director, African Academy of Sciences, Nairobi, Kenya

\section{Sevket Ruacan}

General Director, MESA Hospital Ankara, Turkey

\section{Pramilla Senanayake}

Chairman, Foundation Council of the Global Forum for

Health Research, Colombo, Sri Lanka

\section{Jaime Sepúlveda, Chair}

Director, National Institutes of Health of Mexico, Mexico City, Mexico

\section{Chitr Sitthi-amorn}

Director, Institute of Health Research, and Dean, Chulalongkorn University, College of Public Health, Bangkok, Thailand 


\section{Sally Stansfield}

Associate Director, Global Health Strategies, Bill \& Melinda

Gates Foundation, Seattle, Washington, United States

Misael Uribe

President, National Academy of Medicine of Mexico,

Mexico City, Mexico
Zhengguo Wang

Professor, Chinese Academy of Engineering, Daping, China

Witold Zatonski

Professor, Health Promotion Foundation, Warsaw, Poland 


\section{Contributors}

Taghreed Adam

World Health Organization

Sarah Adomakoh

Chronic Disease Research Centre, University of the West Indies Associates for International Development

Olu Akinyanju

Sickle Cell Foundation, Nigeria

University Teaching Hospital, Nigeria

Mark A. Anderson

U.S. Centers for Disease Control and Prevention

Sevgi O. Aral

U.S. Centers for Disease Control and Prevention

Samira Asma

U.S. Centers for Disease Control and Prevention

Cristian Baeza

World Bank

Rob Baltussen

Erasmus MC

Delia Barcelona

United Nations Population Fund

Scott Barrett

Johns Hopkins University

John H. Barton

Stanford University

Jane Batt

University of Toronto

St. Michaels Hospital

Angela Bayer

Johns Hopkins University Bloomberg School of Public Health

Kathleen Beegle

World Bank
Geneviève Begkoyian

United Nations Children's Fund

Jere R. Behrman

University of Pennsylvania

Nicole Bellows

University of California, Berkeley

Sandra E. Bendeck

University of Texas at Southwestern

Stefano Bertozzi

Instituto Nacional de Salud Pública

Jeff Bethony

George Washington University

Alok Bhargava

University of Houston

Sohinee Bhattacharya

University of Aberdeen

Zulfiqar A. Bhutta

Aga Khan University

Nancy Birdsall

Center for Global Development

David Bishai

Johns Hopkins University

Robert E. Black

Johns Hopkins Bloomberg School of Public Health

Barry R. Bloom

Harvard School of Public Health

Stephen B. Blount

U.S. Centers for Disease Control and Prevention

Cynthia Boschi-Pinto

World Health Organization 


\section{Douglas Bratthall}

World Health Organization Collaborating Centre

Centre for Oral Health Sciences, Malmo University

Carol Brayne

University of Cambridge

Joel G. Breman

Fogarty International Center, National Institutes of Health

Disease Control Priorities Project

Logan Brenzel

World Bank

Dan W. Brock

Harvard Medical School

\section{Simon Brooker}

London School of Hygiene and Tropical Medicine

Peter Brooks

University of Queensland

Claire V. Broome

U.S. Centers for Disease Control and Prevention

L. Jackson Brown

American Dental Association

Martin L. Brown

National Cancer Institute, National Institutes of Health

Nigel Bruce

University of Liverpool

Jennifer Bryce

Independent consultant

Colin H. W. Bullough

University of Aberdeen

Donald A. P. Bundy

World Bank

Alexander Butchart

World Health Organization

Mayra Buvinić

World Bank

Sandy Cairncross

London School of Hygiene and Tropical Medicine

John Cairns

London School of Hygiene and Tropical Medicine

Balla Camara

Ministry of Public Health, Guinea

Ministry of Education, Guinea

Pierre Cattand

Association against Trypanosomiasis
Laura E. Caulfield

Johns Hopkins University Bloomberg School of Public Health

Frank J. Chaloupka

University of Illinois at Chicago

Vijay Chandra

World Health Organization, Regional Office for South-East Asia

Heng Leng Chee

National University of Singapore

Suephy Chen

Emory University

Atlanta Veterans Administration Medical Center

Thomas Cherian

World Health Organization

Tom M. Chiller

U.S. Centers for Disease Control and Prevention

Dan Chisholm

World Health Organization

Lester Chitsulo

World Health Organization

Jeffrey Chow

Resources for the Future

Mushtaque Chowdhury

Bangladesh Rural Advancement Committee

Columbia University

Mariam Claeson

World Bank

Luke B. Connelly

University of Queensland

Joseph Cook

International Trachoma Initiative

Rodrigo Correa-Oliveira

Centro de Pesquisas Rene Rachou-FIOCRUZ

\section{Mark Cullen}

Yale University

Patricia M. Danzon

Wharton School, University of Pennsylvania

Haile T. Debas

University of California, San Francisco

Louisa Degenhardt

University of New South Wales

Lisa M. DeMaria

Instituto Nacional de Salud Pública

xxvi | Contributors 
Nilanthi de Silva

University of Kelaniya, Sri Lanka

Phillippe Desjeux

Institute for OneWorld Health

Claude de Ville de Goyet

Independent consultant

John Dirks

International Society of Nephrology

University of Toronto

Jane Doherty

University of the Witwatersrand, South Africa

Chris Doran

University of Queensland

Ogobara K. Doumbo

University of Bamako, Mali

Gerrit Draisma

Erasmus MC

Lesley Drake

St. Mary's Medical School

\section{Maureen S. Durkin}

University of Wisconsin Medical School

University of Wisconsin-Madison

\section{Adriano Duse}

University of the Witwatersrand, South Africa

National Health Laboratory Service

\section{Courtenay Dusenbury}

Emory University

Christopher Dye

World Health Organization

\section{Michael M. Engelgau}

U.S. Centers for Disease Control and Prevention

\section{Dirk Engels}

World Health Organization

Mike English

Kenya Medical Research Institute

University of Oxford

Victoria Espitia-Hardeman

U.S. Centers for Disease Control and

Prevention

\section{Roberto Estrada}

Universidad Autónoma de Guerrero, Mexico

David B. Evans

World Health Organization
Timothy Evans

World Health Organization

Qiu Fang

World Bank

Piet Feenstra

Royal Tropical Institute, Netherlands

\section{Becca Feldman}

Harvard School of Public Health

Instituto Nacional de Salud Pública

\author{
Alan Fenwick \\ Imperial College \\ Elisa Fernández \\ Inter-American Development Bank \\ Marilyn Fingerhut \\ National Institute for Occupational Safety \\ and Health, United States
}

Katherine Floyd

World Health Organization

Kathleen M. Foley

Memorial Sloan-Kettering Cancer Center

Weill Medical College of Cornell University

Olivier Fontaine

World Health Organization

Susan Foster

Boston University School of Public Health

Julia Fox-Rushby

Brunel University, United Kingdom

Julio Frenk

Secretaria de Salud de Mexico

Kevin D. Frick

Johns Hopkins Bloomberg School of Public Health

Suthat Fucharoen

Mahidol University, Thailand

Vendhan Gajalakshmi

Epidemiological Research Center, India

Rae Galloway

World Bank

Helene Gayle

Bill \& Melinda Gates Foundation

Thomas A. Gaziano

Brigham and Women's Hospital

Harvard Medical School

Hellen Gelband

Institute of Medicine, National Academies 


\section{Amaya Gillespie}

United Nations Study on Violence against Children

\section{Julian Gold}

Prince of Wales Hospital, Australia

Sue J. Goldie

Harvard School of Public Health

Chuck Golmar

World Health Organization

Richard Gosselin

University of California, Berkeley

Pablo Gottret

World Bank

\section{Eduardo Gotuzzo}

Universidad Peruana Cayetano Heredia

Hospital Nacional Cayetano Heredia, Peru

\section{Wendy J. Graham}

University of Aberdeen

London School of Hygiene and Tropical Medicine

\section{Robert Grant}

J. David Gladstone Institutes, United States

\section{Brian Greenwood}

London School of Hygiene and Tropical Medicine

Prakash C. Gupta

Healis-Sekhsaria Institute of Public Health, India

Arnold School of Public Health, United States

\section{M.G. Guzmán}

Pedro Kouri Tropical Medicine Institute, Cuba

\section{Anne Haddix}

Rollins School of Public Health, Emory University

\section{Wayne Hall}

University of Queensland

\section{Neal A. Halsey}

Johns Hopkins University Bloomberg School of Public Health

\section{Joe Harford}

National Cancer Institute, National Institutes of Health

\section{Roderick Hay}

Queen's University Belfast

\section{Robert M. Hecht}

International AIDS Vaccine Initiative

\section{A. Henderson}

University of Pittsburgh Medical Center

\section{Martin Hensher}

Department of Health, United Kingdom

\section{Susan Herman}

University of Pennsylvania

Eduardo Romero Hicks

Secretaria de Salud Guanajuato, Mexico

University of Guanajuato, Mexico

Anna-Maria Hoffman

United Nations Educational Scientific, and Cultural Organization

\section{Karen J. Hofman}

Fogarty International Center, National Institutes of Health

\section{King K. Holmes}

University of Washington

Harborview Medical Center

Charles Hongoro

London School of Hygiene and Tropical Medicine

Aurum Health Research Institute

\section{Susan Horton}

Wilfrid Laurier University, Canada

Peter J. Hotez

George Washington University

Fleur Hourihan

University of Newcastle, Australia

Guy Hutton

Swiss Tropical Institute

Adnan A. Hyder

Johns Hopkins Bloomberg School of Public Health

Steven Hyman

Harvard University

Harvard Medical School

Giuseppina Imperatore

U.S. Centers for Disease Control and Prevention

\section{Rubina Imtiaz}

U.S. Centers for Disease Control and Prevention

\section{Michael T. Isbell}

Independent consultant

Dean T. Jamison

University of California, San Francisco

Disease Control Priorities Project

Jean Jannin

World Health Organization 
Philip Jenkins

World Health Organization

Prabhat Jha

University of Toronto

Centre for Global Health Research

\section{T. Jacob John}

Christian Medical College (retired)

National HIV/AIDS Reference Center, India (retired)

Jack Jones

World Health Organization

David E. Joranson

University of Wisconsin Comprehensive Cancer Center

World Health Organization

Manjul Joshipura

Academy of Traumatology, India

Apollo Hospitals, India

Matthew Jukes

Imperial College London

Alka M. Kanaya

University of California, San Francisco

Scott Kasner

University of Pennsylvania

Ronald Kessler

Harvard Medical School

Gerald T. Keusch

Boston University Medical Campus

Boston University School of Public Health

\section{Peter Kilima}

International Trachoma Initiative

\section{Sally Kingsland}

National Centre for Epidemiology and Population Health, Australian National University

Tord Kjellström

Australian National University

National Institute of Public Health, Sweden

Keith P. Klugman

Rollins School of Public Health, Emory University

Felicia Knaul

Fundación Mexicana para la Salud

Secretaria de Educación Pública de Mexico

\section{Rudolf Knippenberg}

United Nations Children's Fund

James C. Knowles

Independent consultant
Olive C. Kobusingye

World Health Organization Regional Office for Africa

Jeffrey P. Koplan

Emory University

Daniel Kress

Bill \& Melinda Gates Foundation

A. Kroeger

World Health Organization

Richard Laing

Boston University School of Public Health, now World Health Organization

John R. La Montagne (Deceased)

National Institute of Allergy and Infectious Diseases, National Institutes of Health

Claudio F. Lanata

Instituto de Investigación Nutricional, Peru

Ana Langer

EngenderHealth

Carlene M. M. Lawes

University of Auckland

Joy E. Lawn

Save the Children-USA

Institute of Child Health

Ramanan Laxminarayan

Resources for the Future

Seung-Hee Frances Lee

Save the Children-USA

Christian Lengeler

Swiss Tropical Institute

\section{P. R. Lever}

Royal Tropical Institute, Netherlands

\section{Ruth Levine}

Center for Global Development

Joseph Lipscomb

Rollins School of Public Health, Emory University

Madhumita Lodh

Commonwealth Department of Transport and Regional Services, Australia

Alan Lopez

University of Queensland

Harvard School of Public Health

Elizabeth Lule

World Bank 


\section{Antoine Mahé}

Programme National de Lutte Contre le SIDA

\section{Adel Mahmoud}

Merck \& Company Inc.

Case Western Reserve University

Margaret Maier

RAND Corporation

Lisa Manhart

University of Washington

Bala Manyam

Texas A\&M University HSC School of Medicine

Paola Marchesini

World Health Organization

\section{Maureen S. Marshall}

Task Force for Child Survival and Development

John B. Mason

Tulane University School of Public Health and Tropical Medicine

Gaverick Matheny

University of Maryland

Colin McCord

Columbia University

Martin McKee

London School of Hygiene and Tropical Medicine

Tonya McLeod

Emory University

Tony McMichael

Australian National University

\section{Anthony R. Measham}

World Bank (retired)

Disease Control Priorities Project

Jeffrey Mecaskey

Axios International

\section{André Médici}

Inter-American Development Bank

\section{Carol Ann Medlin}

University of California, San Francisco

Sumi Mehta

World Health Organization

Health Effects Institute

Bjørn Melgaard

World Health Organization

\section{David Meltzer}

University of Chicago

Kamini Mendis

World Health Organization

James Mercy

U.S. Centers for Disease Control and Prevention

Catherine Michaud

Harvard School of Public Health

Mark Miller

Fogarty International Center, National Institutes of Health

Anne Mills

London School of Hygiene and Tropical Medicine

Andrew Mitchell

Harvard School of Public Health

Arlene Mitchell

World Food Programme

Charles Mock

University of Washington

Harborview Medical Center

Antonio Montresor

World Health Organization

James Moore

U.S. Centers for Disease Control and Prevention

Chantal Morel

London School of Hygiene and Tropical Medicine Oxford Outcomes

Luis Morillo

Javeriana University

Roy D. Mugerwa

Makerere University, Uganda

Case Western Reserve University

Jo-Ann Mulligan

London School of Hygiene and Tropical Medicine

Philip Musgrove

Health Affairs

Disease Control Priorities Project

Vasant Narasimhan

Novartis Pharma AG, Switzerland

K. M. Venkat Narayan

Centers for Disease Control and Prevention

Rollins School of Public Health at Emory University 
Mike B. Nathan

World Health Organization

\section{Karin B. Nelson}

National Institute for Neurological Disorders and Stroke, National Institutes of Health

Isaac Ngugi

KEMRI/Wellcome Trust Programme, Kenya

Mounkaila Noma

African Programme for Onchocerciasis Control

Charles Normand

University of Dublin, Trinity College

London School of Hygiene and Tropical Medicine

\section{Robyn Norton}

George Institute for International Health

University of Sydney

Peter Nsubuga

U.S. Centers for Disease Control and Prevention

\section{Rachel Nugent}

Population Reference Bureau

Fogarty International Center, National Institutes of Health

Thomas O'Brien

Brigham and Women's Hospital

\section{Adesola Ogunniyi}

University of Ibadan

University College Hospital, Nigeria

Iruka N. Okeke

Haverford College

Eidgenossische Technische Hochschule, Switzerland

\section{Nancy Olivieri}

Hemoglobinopathy Research Program, University Health

Network, Canada

\section{Claudio Osorio}

Pan American Health Organization

Mead Over

World Bank

\section{Ariel Pablos-Mendez}

World Health Organization

Columbia University

\section{Fred Paccaud}

University of Lausanne

University of Montreal

Nancy S. Padian

University of California, San Francisco
Rajesh Pandav

World Health Organization, Regional Office for

South-East Asia

Vikram Patel

London School of Hygiene and Tropical Medicine

Vikram S. Pathania

University of California, Berkeley

John W. Peabody

University of California, San Francisco

University of California, Los Angeles

Richard Peck

University of Illinois at Chicago

Margie Peden

World Health Organization

Poul Erik Petersen

World Health Organization

Ndola Prata

University of California, Berkeley

Alexander S. Preker

World Bank

Max Price

University of the Witwatersrand, South Africa

Pekka Puska

National Public Health Institute, Finland

Zahidul Quayyum

University of Aberdeen

Sadanand Rajkumar

University of Newcastle

Bloomfield Hospital

Ambady Ramachandran

M.V. Hospital for Diabetes, India

Diabetes Research Centre, India

K. D. Ramaiah

Vector Control Research Centre, India

Geetha Ranmuthugala

Australian National University

Fawzia Rasheed

Independent consultant

K. Srinath Reddy

All India Institute of Medical Sciences

Initiative for Cardiovascular Health in the Developing Countries

Eva Rehfuess

World Health Organization 


\section{Jürgen Rehm}

Centre for Addiction and Mental Health, Canada

ISGF/ARI, Switzerland

Jan H. F. Remme

World Health Organization

Giuseppe Remuzzi

Mario Negri Institute for Pharmacological Research, Italy

Azienda Ospedaliera Ospedali Riuniti di Bergamo, Italy

Serge Resnikoff

World Health Organization

Stephanie A. Richard

Johns Hopkins University Bloomberg School of

Public Health

\section{Frank Richards}

U.S. Centers for Disease Control and Prevention

The Carter Center of Emory University

Juan A. Rivera

Instituto Nacional de Salud Pública, Mexico

\section{S. Adibul Hasan Rizvi}

Sindh Institute of Urology and Transplantation

\section{David A. Robalino}

World Bank

Anthony Rodgers

University of Auckland

Khama Rogo

World Bank

Robin Room

Stockholm University

James E. Rosen

World Bank

Mark L. Rosenberg

Task Force for Child Survival and

Development

\section{Linda Rosenstock}

University of California, Los Angeles

David Sanders

University of the Western Cape

Lorenzo Savioli

World Health Organization

Richard M. Scheffler

University of California, Berkeley

George Schieber

World Bank

\section{Arrigo Schieppati}

Mario Negri Institute for Pharmacological

Research, Italy

Azienda Ospedaliera Ospedali Riuniti di Bergamo, Italy

Gabriel Schmunis

Pan American Health Organization

Helen Schneider

University of the Witwatersrand, South Africa

C. J. Schofield

London School of Hygiene and Tropical Medicine

A. Seketeli

African Programme for Onchocerciasis Control

Malick Sembene

Ministry of National Education, Senegal

Sheldon Shaeffer

United Nations Educational, Scientific, and

Cultural Organization

Raj J. Shah

Bill \& Melinda Gates Foundation

Sonbol A. Shahid-Salles

Disease Control Priorities Project

Population Reference Bureau

Brian Sharp

Medical Research Council

Alexandra Shaw

AP Consultants

\section{Donald Shepard}

Schneider Institute for Health Policy, Heller School, Brandeis University

Rupendra Shrestha

Australian National University

Xiao Shu-Hua

National Institute of Parasitic Diseases, China

Donald Silberberg

University of Pennsylvania

Eric A. F. Simoes

University of Colorado Health Sciences Center

Children's Hospital

Lone Simonsen

National Institute of Allergy and Infectious Diseases, National Institutes of Health

Susheela Singh

Alan Guttmacher Institute, United States 
Arthur S. Slutsky

St. Michael's Hospital

University of Toronto

Andrew Smith

World Health Organization

Kirk Smith

School of Public Health, University of California, Berkeley

Peter C. Smith

Centre for Health Economics, University of York

Robert W. Snow

Centre for Tropical Medicine, University of Oxford

Kenya Medical Research Institute

\section{Soekirman}

Institut Pertanian Bogor, Indonesia

Geoffrey C. Solarsh

Monash University, Australia

Dan Sosin

U.S. Centers for Disease Control and Prevention

\section{Frank E. Speizer}

Harvard Medical School

Harvard School of Public Health

\section{Sally K. Stansfield}

Bill \& Melinda Gates Foundation

University of Washington

Richard W. Steketee

PATH

Jayanthi Ramanathan Stjernswärd

Malmø University

Stephen E. Straus

National Center for Complementary and Alternative Medicine, National Institutes of Health

Donna F. Stroup

U.S. Centers for Disease Control and Prevention

Mario M. Taguiwalo

Department of Health, Republic of the Philippines

Tsutomu Takeuchi

School of Medicine, Keio University, Japan

Caroline Tanner

Parkinson's Institute

Robert V. Tauxe

U.S. Centers for Disease Control and

Prevention
Stephen B. Thacker

U.S. Centers for Disease Control and Prevention

William Theodore

National Institute for Neurological Disorders and Stroke, National Institutes of Health

Amardeep Thind

University of Western Ontario

University of California, Los Angeles

Stephen Tollman

Medical Research Council

University of the Witwatersrand, South Africa

Ana Cristina Torres

World Bank

Murray Trostle

U.S. Agency for International Development

Vivian Valdmanis

University of the Sciences in Philadelphia

W. H. van Brakel

Royal Tropical Institute, Netherlands

Anna Vassall

Royal Tropical Institute, Netherlands

Cesar G. Victora

Universidade Federal de Pelotas, Brazil

Maya Vijayaraghavan

U.S. Centers for Disease Control and Prevention

Theo Vos

University of Queensland

Judith L. Wagner

Institute of Medicine, United States

Adam Wagstaff

World Bank

Julia Walsh

University of California, Berkeley

Prawese Wasi

Siriraj Hospital

Mahidol University

Hugh Waters

Johns Hopkins University Bloomberg

School of Public Health

David Weatherall

University of Oxford

Jeny Wegbreit

University of California, San Francisco 
Mark E. White

U.S. Centers for Disease Control and Prevention

\section{Nicholas J. White}

Mahidol University, Thailand

University of Oxford

\section{Harvey Whiteford}

University of Queensland

\section{Daniel Wikler}

Harvard School of Public Health

\section{Suwit Wilbulpolprasert}

Ministry of Public Health, Thailand

\section{Walter C. Willett}

Harvard School of Public Health

Harvard Medical School

\section{Desmond E. Williams}

U.S. Centers for Disease Control and Prevention

\section{Lara J. Wolfson}

World Health Organization

\section{Anthony Woolf}

Peninsula Medical School, United Kingdom

Royal Cornwall Hospital, United Kingdom

\section{Cream Wright}

United Nations Children's Fund

\section{Merrick Wright}

Independent consultant

Michel Zaffran

World Health Organization

Ricardo Zapata Marti

United Nations Economic Commission for Latin America and Caribbean

\section{Witold Zatonski}

Cancer Center and Institute of Oncology, Poland Health Promotion Foundation

\section{Ping Zhang}

U.S. Centers for Disease Control and Prevention

\section{Zhen-Xin Zhang}

Peking Union Medical College Hospital

Chinese Academy of Medical Science

Jelka Zupan

World Health Organization 


\section{Disease Control Priorities Project Partners}

The Disease Control Priorities Project is a joint enterprise of the Fogarty International Center of the National Institutes of Health, the World Health Organization, the World Bank, and the Population Reference Bureau.

The Fogarty International Center is the international component of the U.S. National Institutes of Health. It addresses global health challenges through innovative and collaborative research and training programs and supports and advances the mission of the U.S. National Institutes of Health through international partnerships.

The World Health Organization is the specialized agency for health of the United Nations. Its objective, as set out in its constitution, is the attainment by all peoples of the highest possible level of health, with health defined as a state of complete physical, mental, and social well-being and not merely the absence of disease or infirmity.

The World Bank Group is one of the world's largest sources of development assistance. The Bank, which provides
US $\$ 18$ billion to US $\$ 22$ billion each year in loans to its client countries, provided US $\$ 1.27$ billion for health, nutrition, and population in 2004. The World Bank is working in more than 100 developing economies, bringing a mix of analytical work, policy dialogue, and lending to improve living standardsincluding health and education —and reduce poverty.

The Population Reference Bureau informs people around the world about health, population, and the environment and empowers them to use that information to advance the wellbeing of current and future generations. For 75 years, the bureau has analyzed complex data and research results to provide objective and timely information in a format easily understood by advocates, journalists, and decision makers; has conducted workshops around the world to give key audiences the tools they need to understand and communicate effectively about relevant issues; and has worked to ensure that policy makers in developing countries base policy decisions on sound evidence. 



\section{Acknowledgments}

Preparation of this volume required efforts over four years by many institutions and almost 1,000 individuals: chapter coauthors, advisory committee members, peer reviewers, copy editors, and research and staff assistants. We have many contributions to acknowledge. We particularly thank our chapter authors, who worked extremely hard through a long and exacting process of writing, review, and revision. We also owe much gratitude to the institutional sponsors of this effort:

- The Fogarty International Center (FIC) of the U.S. National Institutes of Health. The FIC supported both the senior editor and one of the co-managing editors of this project, as well as support staff. Gerald Keusch, former director of the FIC, initiated and facilitated this effort, and FIC's acting director, Sharon Hrynkow, continued to provide support and counsel.

- The World Bank. Successive directors of the World Bank's Health, Nutrition, and Population Department, Christopher Lovelace and Jacques Baudouy, provided support, guidance, and critical reactions and facilitated the involvement of Bank staff as coauthors and reviewers.

- The World Health Organization. Successive leaders of the World Health Organization's Evidence and Information for Policy Cluster, Christopher Murray and Timothy Evans, coordinated the involvement of the World Health Organization, which had been agreed by Gro Harlem Brundtland, then the director-general.

- The Bill \& Melinda Gates Foundation. Richard Klausner, Sally Stansfield, and Beth Peterman arranged for the foundation to provide major financial support and interacted closely with us throughout the past four years. Initial conversations with and encouragement from William Gates Senior are gratefully acknowledged.

In undertaking the work leading to this volume, we benefited from the close engagement of three institutions that helped organize and host consultations and arranged for background analyses to be undertaken. These institutions were the London School of Hygiene and Tropical Medicine (Anne Mills), the University of Toronto's Center for Global Health
(Prabhat Jha), and Resources for the Future (Ramanan Laxminarayan). The Center for Global Development (Ruth Levine) collaborated with the chapter authors in an effort to identify proven successes in global health, the results of which were used both in this book and in a separate publication. We are grateful to each of these institutions and individuals.

We were particularly fortunate to have the strong collaboration of the Inter-Academies Medical Panel (IAMP), an association of the medical academies or medical divisions of the scientific academies of 44 countries. David Challoner and Guy de The cochaired the Steering Committee of the IAMP and invested much time and effort into facilitating the collaboration. In particular, the IAMP helped establish the productive Advisory Committee to the Editors, chaired by Jaime Sepúlveda, on which many members of the IAMP Steering Committee served. The IAMP's second global meeting hosted the launch of this volume in Beijing in April 2006, and the IAMP also sponsored the peer review process for all the chapters. We are most grateful to David Challoner and Guy de Thé, as well as to Jaime Sepúlveda and other members of the Advisory Committee to the Editors. The U.S. member of the IAMP, the Institute of Medicine of the National Academy of Sciences, played a critical role in facilitating all aspects of the IAMP's collaboration. Patrick Kelley, Patricia Cuff, Dianne Stare, Stacey Knobler, and Leslie Baer at the Institute of Medicine and Mohamed Hassan and Muthoni Fanin at the IAMP managed this effort and provided critical, substantive inputs.

The Office of the Publisher at the World Bank provided outstanding assistance, enthusiastic advice, and support during every phase of production of this volume and helped coordinate publicity and initial distribution. We particularly wish to thank Dirk H. Koehler, the publisher; Carlos Rossel; Mary Fisk; Santiago Pombo-Bejarano; Nancy Lammers; Randi Park; Valentina Kalk; Alice Faintich; Joanne Ainsworth; Enid Zafran; Deepa Menon; and Janice Tuten for their timely, high-quality professionalism.

Donald Lindberg, director of the National Library of Medicine (NLM) of the U.S. National Institutes of Health, and Julia Royall, chief, International Programs, NLM, graciously 
offered the competent services of the NLM's Information Engineering Branch of the National Center for Biotechnology Information to convert the text into an electronic product available to all visitors to the National Library of Medicine's PubMed Web site. We would like to extend our gratitude to the National Center for Biotechnology Information team members-David Lipman, Jo McEntyre, and Mohammad Al-Ubaydli, and Belinda Beck-for their technical expertise and commitment.

With this volume now in the dissemination phase, the Population Reference Bureau is charged to communicate its findings in formats likely to be of use to a range of audiences. We greatly value the work of the bureau's William P. Butz, president, and Nancy Yinger, director of international programs, in rapidly initiating this effort.

Multiple institutions from around the world contributed to organizing and hosting meetings that facilitated the preparation of this book and providing background for such meetings. We greatly appreciate the contributions and hospitality of these institutions, including the following:

- Chinese Academy of Engineering and Chinese Academy of Sciences, Disease Control Priorities Project Launch and Inter-Academies Medical Panel Global Meeting, Beijing, China (April 2006)

- Italian Ministry of Health, Veneto Region, consultation on child health and nutrition, Venice, Italy (January 2004)

- Instituto Nacional de Salud Pública, Advisory Committee to the Editors meeting, Cuernavaca, Mexico (June 2002)

- Institut Pasteur, Advisory Committee to the Editors meeting, Paris, France (March and December 2004)

- Johns Hopkins Bloomberg School of Public Health, consultation on maternal and child health, Annapolis, Maryland (May 2002)

- Johns Hopkins Paul H. Nitze School of Advanced International Studies, consultation on elimination and eradication of disease, and vaccinations, Washington, DC (October 2004)

- Merck \& Company Inc., consultation on research and product development priorities, Whitehouse Station, New Jersey (September 2004)

- Multilateral Initiative on Malaria, consultations on the burden of malaria:

- National Institute of Medical Research, Arusha, Tanzania (November 2002)

- University of Yaoundé, Cameroon (November 2005)
- National Cancer Institute, National Institutes of Health, consultation on cancer prevention, treatment, and pain control, Bethesda, Maryland (June 2003)

- Oswaldo Cruz Foundation, World Health Organization, and Pan-American Health Organization, consultation on tropical infectious diseases, Rio de Janeiro, Brazil (April-May 2003)

- Université de Lausanne, consultation on cardiovascular disease, Lausanne, Switzerland (March 2002)

- University of California, Berkeley, consultation on learning and developmental disorders, Berkeley, California (August 2003)

- University of California, San Francisco, consultation on surgery, San Francisco, California (July 2003)

- University of Queensland, School of Population Health, authors' meeting on psychiatric disorders, neurology, and alcohol and other substance abuse, Brisbane, Australia (August 2003)

- University of Washington, consultation on sexually transmitted infections, Seattle, Washington (July 2003)

- University of the Witwatersrand, consultations on health systems and on capacity strengthening and management reform, Johannesburg, South Africa (July 2004)

- World Health Organization, Division of Mental Health, and National Institutes of Health, National Institute of Mental Health, consultation on mental health economics, Geneva, Switzerland (March 2004).

Coordination of the work leading to this publication and background research were undertaken by a small secretariat. Nancy Hancock, Pamela Maslen, and Sonbol A. Shahid-Salles provided outstanding research assistance; Andrew Marshall ably managed the budget and process; Candice Byrne provided key communications guidance, staff and editorial assistance; and Mantra Singh and Cherice Holloway provided staff assistance. Richard Miller, Lauren Sikes and Tommy Freeman of the FIC provided excellent administrative support to the Disease Control Priorities Project. Their work was absolutely essential in producing this book, and we are deeply grateful for their commitment and productivity. With so many authors and institutions involved, we are aware that many more people gave countless hours to this endeavor. We thank them also for their dedication.

The Editors 


\section{Abbreviations and Acronyms}

\begin{tabular}{|c|c|c|c|}
\hline ACE & angiotensin-converting enzyme & CBR & cost-benefit ratio \\
\hline ACER & average cost-effectiveness ratio & CDC & U.S. Centers for Disease Control and Prevention \\
\hline ACT & artemisinin combination therapy & CDD & control of diarrheal diseases \\
\hline $\mathrm{AD}$ & Alzheimer's disease & CEA & cost-effectiveness analysis \\
\hline $\mathrm{ADB}$ & Asian Development Bank & CEmOC & comprehensive emergency obstetric care \\
\hline ADHD & attention deficit and hyperactivity disorder & CER & cost-effectiveness ratio \\
\hline AED & antiepileptic drug & CFR & case-fatality rate \\
\hline AIDS & acquired immunodeficiency syndrome & $\mathrm{CHD}$ & coronary heart disease \\
\hline AIN-C & atención integral a la niñez comunitaria & $\mathrm{CHF}$ & congestive heart failure \\
\hline ALRI & acute lower respiratory infection & CHNP & community-based health and nutrition program \\
\hline AMI & acute myocardial infarction & CHNW & community health and nutrition worker \\
\hline ANW & anganwadi worker & CHOICE & choosing interventions that are cost-effective \\
\hline ARI & acute respiratory infection & $\mathrm{CL} / \mathrm{P}$ & cleft lip and palate \\
\hline ART & atraumatic restorative treatment & CM & cerebral malaria \\
\hline ASD & autism spectrum disorder & $\mathrm{CMH}$ & Commission on Macroeconomics and Health \\
\hline ATLS & advanced trauma life support & CML & chronic myeloid leukemia \\
\hline AUD & alcohol-use disorder & $\mathrm{CO}$ & carbon monoxide \\
\hline $\mathrm{AZT}$ & Zidovudine & COBRA & combination therapy for rheumatoid arthritis \\
\hline BCC & behavior-change communication & COHRED & Council on Health Research for Development \\
\hline BCG & Bacillus Calmette-Guérin & $\mathrm{COM}$ & chronic otitis media \\
\hline BEmOC & basic emergency obstetric care & COPCORD & Community-Oriented Program for Control of \\
\hline BINP & Bangladesh Integrated Nutrition Program & & Rheumatic Disease \\
\hline CABG & coronary artery bypass graft & CVS & chorionic villus sampling \\
\hline CAD & coronary artery disease & CYP & couple-year of protection \\
\hline CAM & complementary and alternative medicine & $\mathrm{DAH}$ & development assistance for health \\
\hline CAPP & Country/Area Profile Programme & DALY & disability-adjusted life year \\
\hline CBA & cost-benefit analysis & $\mathrm{dBHL}$ & decibel hearing level \\
\hline $\mathrm{CBE}$ & clinical breast examination & $D C P 1$ & Disease Control Priorities in Developing \\
\hline $\mathrm{CBHI}$ & community-based health insurance & & Countries, first edition \\
\hline
\end{tabular}




\begin{tabular}{|c|c|c|c|}
\hline$D C P 2$ & $\begin{array}{l}\text { Disease Control Priorities in Developing } \\
\text { Countries, second edition }\end{array}$ & $\begin{array}{l}\text { GFHR } \\
\text { GIS }\end{array}$ & $\begin{array}{l}\text { Global Forum on Health Research } \\
\text { geographic information system }\end{array}$ \\
\hline DCPP & Disease Control Priorities Project & GM & genetic modification \\
\hline DDT & dichlorodiphenyltrichloroethane & GMP & good manufacturing practice \\
\hline DEET & N,N-diethyl-meta-toluamide & GNI & gross national income \\
\hline DF & dengue fever & GNP & gross national product \\
\hline DHF & dengue hemorrhagic fever & GSE & glutathione S-transferase \\
\hline DHS & demographic and health survey & GUSTO & global use of strategies to open occluded \\
\hline DMARD & disease-modifying antirheumatic drug & & coronary arteries \\
\hline DMFT & decayed, missing, and filled teeth & HAART & highly active antiretroviral therapy for the \\
\hline DNA & deoxyribose nucleic acid & & treatment of HIV/AIDS \\
\hline DOT & directly observed therapy & $\mathrm{Hb}$ & hemoglobin \\
\hline DOTS & directly observed therapy short course & $\mathrm{HBV}$ & hepatitis B virus \\
\hline DRC & Democratic Republic of Congo & HDL & high-density lipoprotein \\
\hline DSM-IVTR & Diagnostic and Statistical Manual of Mental & НерB & hepatitis B \\
\hline & Disorders & HHV & human herpes virus \\
\hline DSS & dengue shock syndrome & Hib & Haemophilus influenzae type B \\
\hline DTP & diphtheria-tetanus-pertussis & HIC & high-income country \\
\hline EAP & economically active population & HIS & health information system \\
\hline EBM & evidence-based medicine & HIV & human immunodeficiency virus \\
\hline $\mathrm{ED}$ & emergency department & HMN & Health Metrics Network \\
\hline EFA & education for all & HPLC & high-performance liquid chromatography \\
\hline EFM & electronic fetal monitoring & HPS & health promoting school \\
\hline EHCAP & Effective Health Care Alliance Programme & $\mathrm{HPV}$ & human papillomavirus \\
\hline EIR & entomological inoculation rate & HR & human resource \\
\hline ELISA & enzyme-linked immunosorbent assay & HRT & hormone replacement therapy \\
\hline EMR & electronic medical record & HSV-1 & herpes simplex virus type 1 \\
\hline EMS & emergency medical services & HSV-2 & herpes simplex virus type 2 \\
\hline EPI & Expanded Program on Immunization & IAEA & International Atomic Energy Agency \\
\hline ESRD & end-stage renal disease & IAP & indoor air pollution \\
\hline EUROSTAT & European Statistical Office & IAVI & International AIDS Vaccine Initiative \\
\hline FA & folic acid & ICD-10 & International Statistical Classification of Diseases \\
\hline FBD & food-borne disease & & and Related Health Problems, 10th revision \\
\hline FCTC & Framework Convention on Tobacco Control & ICDS & integrated child development services \\
\hline FDA & U.S. Food and Drug Administration & ICER & incremental cost-effectiveness ratio \\
\hline FDC & fixed-dose combinations & ICPD & international conference on population and \\
\hline FEFO & first expiry, first out & & development \\
\hline FETP & Field Epidemiology Training Program & ICT & information and communication \\
\hline FEV1 & forced expiratory volume in one second & & technologies \\
\hline FGM & female genital mutilation & IDA & International Development Association \\
\hline FHP & family health program & IDD & iodine deficiency disorders \\
\hline FIC & fully immunized child & IDSR & integrated disease surveillance and response \\
\hline FRESH & focusing resources on effective school health & IEC & information, education, and communication \\
\hline FTE & full-time equivalent & IFF & International Finance Facility \\
\hline G6PD & glucose-6-phosphate dehydrogenase & IHD & ischemic heart disease \\
\hline G-7 & Group of Seven & ILO & International Labour Organisation \\
\hline GATB & Global Alliance for TB Drug Development & IMCI & integrated management of infant and childhood \\
\hline GAVI & Global Alliance for Vaccines and Immunization & & illness \\
\hline GDP & gross domestic product & IMF & International Monetary Fund \\
\hline \multirow[t]{2}{*}{ GET 2020} & World Health Organization Alliance for the & IMR & infant mortality rate \\
\hline & Global Elimination of Trachoma & INCB & International Narcotics Control Board \\
\hline
\end{tabular}




\begin{tabular}{|c|c|c|c|}
\hline \multirow[t]{4}{*}{ INDEPTH } & International Network of Field Sites with & MR & mental retardation \\
\hline & Continuous Demographic Evaluation of & MRI & magnetic resonance imaging \\
\hline & Populations and Their Health in Developing & MSF & Médecins Sans Frontières (Doctors Without \\
\hline & Countries & & Borders) \\
\hline \multirow[t]{3}{*}{ INFECTOM } & information, feedback, contracting with & MTCT & mother-to-child transmission \\
\hline & providers to adhere to practice guidelines, and & MVA & modified vaccinia virus Ankara \\
\hline & ongoing monitoring & NAFTA & North American Free Trade Agreement \\
\hline IPT & intermittent preventive treatment & NAP & nonaffective psychosis \\
\hline IPTi & $\begin{array}{l}\text { intermittent preventive treatment in } \\
\text { infancy }\end{array}$ & NCCAM & $\begin{array}{l}\text { National Center for Complementary and } \\
\text { Alternative Medicine }\end{array}$ \\
\hline IPV & inactivated polio vaccine & NCE & new chemical entity \\
\hline IRB & institutional review board & NDP & national drug policy \\
\hline IRR & internal rate of return & NGO & nongovernmental organization \\
\hline IRS & indoor residual spraying & NHA & national health account \\
\hline ISDR & international strategy for disaster reduction & NHS & national health service \\
\hline \multirow[t]{2}{*}{ ISIC } & international standard industrial classification of & $\mathrm{NIH}$ & National Institutes of Health \\
\hline & all economic activities & $\mathrm{NIOSH}$ & National Institute for Occupational Safety \\
\hline ITN & insecticide-treated net & & and Health \\
\hline \multirow[t]{2}{*}{ IUATLD } & International Union against Tuberculosis and & NIPA & national income and product accounts \\
\hline & Lung Disease & NMR & neonatal mortality rate \\
\hline IUD & intrauterine device & $\mathrm{NO}_{2}$ & nitrogen dioxide \\
\hline IUGR & intrauterine growth retardation & NORA & national occupational research agenda \\
\hline $\mathrm{JE}$ & Japanese encephalitis & NOx & nitrogen oxide and nitrogen dioxide \\
\hline LAAM & levo-alpha-acetyl-methadol & NRA & national regulatory authority \\
\hline LBW & low birthweight & NRT & nicotine replacement therapies \\
\hline LDD & learning and developmental disability & NSAID & nonsteroidal anti-inflammatory drug \\
\hline LDL & low-density lipoprotein & NSO & national statistics office \\
\hline LE 20 & life expectancy at age 20 & NTD & neural tube defect \\
\hline LF & lymphatic filariasis & $\mathrm{OA}$ & osteoarthritis \\
\hline LIC & low-income country & OCP & Onchocerciasis Control Program \\
\hline LMICs & low- and middle-income countries & ODA & official development assistance \\
\hline LPG & liquid petroleum gas & OECD & Organisation for Economic Co-operation \\
\hline LRI & lower respiratory tract infection & & and Development \\
\hline LSD & lysergic acid diethylamide & OEPA & Onchocerciasis Elimination Program \\
\hline MBB & marginal budgeting for bottlenecks & & for the Americas \\
\hline \multirow[t]{2}{*}{ MCE } & multi-country evaluation of IMCI effectiveness, & $\mathrm{OP}$ & osteoporosis \\
\hline & cost, and impact & OPV & oral polio vaccine \\
\hline $\mathrm{MCH}$ & maternal child and health & ORS & oral rehydration solution \\
\hline MDA & mass drug administration & ORT & oral rehydration therapy \\
\hline MDG & Millennium Development Goal & PAHO & Pan American Health Organization \\
\hline MDMA & methylenedioxymethamphetamine & PAL & practical approach to lung health \\
\hline MDR-TB & multidrug-resistant tuberculosis & PARIS21 & Partnership in Statistics for Development in the \\
\hline MDT & multidrug therapy & & 21st Century \\
\hline \multirow[t]{2}{*}{ MEASURE } & monitoring and evaluation to assess and use & PCBs & polychlorinated biphenyls \\
\hline & results & PCD & Partnership for Child Development \\
\hline MIC & middle-income country & PCP & Pneumocystis carinii pneumonia \\
\hline MMR & measles-mumps-rubella & PCR & polymerase chain reaction \\
\hline MMT & methadone maintenance treatment & PCV & protein-conjugated polysaccharide vaccine \\
\hline MMV & Medicines for Malaria Venture & $\mathrm{PD}$ & Parkinson's disease \\
\hline $\mathrm{MNCH}$ & maternal, neonatal, and child health & $\mathrm{PDOH}$ & Philippine Department of Health \\
\hline $\mathrm{MOH}$ & ministry of health & PDSA & plan-do-study-act \\
\hline
\end{tabular}




\begin{tabular}{|c|c|c|c|}
\hline PFGE & pulsed-field-gel-electrophoresis & TB & tuberculosis \\
\hline PHC & primary health care & TCA & tricyclic antidepressant \\
\hline PHSWOW & public health school without walls & TDR & Special Programme for Research and Training in \\
\hline PLACE & Priorities for Local AIDS Control Effort & & Tropical Diseases \\
\hline $\mathrm{PM}$ & particulate matter & TEHIP & Tanzania Essential Health Interventions \\
\hline PMTCT & prevention of mother-to-child transmission & & Program \\
\hline PopEd & population and family life education & THC & tetrahydrocannabinol \\
\hline PPPs & public-private partnerships & TLTI & treatment for latent tuberculosis infection \\
\hline PRSC & poverty reduction support credit & TLV & threshold limit value \\
\hline PRSP & Poverty Reduction Strategy Paper & TM & traditional medicine \\
\hline PSV & polysaccharide vaccine & TRIPS & Agreement on Trade-Related Aspects of \\
\hline PTA & parent-teacher association & & Intellectual Property Rights \\
\hline QALY & quality-adjusted life year & UNESCO & United Nations Education, Scientific, and \\
\hline RA & rheumatoid arthritis & & Cultural Organization \\
\hline $\mathrm{R} \& \mathrm{D}$ & research and development & UNFPA & United Nations Population Fund \\
\hline RCT & randomized clinical trial & UNICEF & United Nations Children’s Fund \\
\hline RDI & recommended dietary intake & UNIDO & United Nations Industrial Development \\
\hline RESU & regional epidemiology and surveillance unit & & Organization \\
\hline RHD & rheumatic heart disease & URI & upper respiratory tract infection \\
\hline RNA & ribonucleic acid & USAID & U.S. Agency for International Development \\
\hline $\mathrm{ROP}$ & retinopathy of prematurity & VAD & vitamin A deficiency \\
\hline RRT & renal replacement therapy & $\mathrm{VC}$ & vital capacity \\
\hline SAR & search and rescue & VOI & value-of-information (techniques) \\
\hline SARS & severe acute respiratory syndrome & VSL & value of a statistical life \\
\hline SBP & systolic blood pressure & WFP & World Food Programme \\
\hline SCC & short-course chemotherapy & WHA & World Health Assembly \\
\hline SD & standard deviation & WHO & World Health Organization \\
\hline $\mathrm{SiC}$ & significant caries (index) & WHO/TDR & WHO Special Programme for Research and \\
\hline SMA & severe malarial anemia & & Training in Tropical Diseases \\
\hline $\mathrm{SO}_{2}$ & sulfur dioxide & WHOCC & WHO Collaborating Center \\
\hline SP & sulfadoxine-pyrimethamine & WISE & work improvement in small enterprises \\
\hline SSO & social security organization & WTO & World Trade Organization \\
\hline SSRI & selective serotonin reuptake inhibitor & YF & yellow fever \\
\hline STATCAP & statistical capacity building & YLD & year of life lived with disability \\
\hline STH & soil-transmitted helminth & YLL & year of life lost \\
\hline STI & sexually transmitted infection & YLS & year of life saved \\
\hline SWAp & sectorwide approach & & \\
\hline
\end{tabular}

All dollar amounts are U.S. dollars unless otherwise indicated. 